\title{
THE FOSSILS OF CASTOR FIBER FROM THE MIDDLE PLEISTOCENE SITE OF GRUTA DA AROEIRA (PORTUGAL) AND HUMAN-BEAVER INTERACTION
}

\author{
Gloria CUENCA-BESCÓS ${ }^{1}$, Montserrat SANZ ${ }^{2,3}$, Joan DAURA ${ }^{2,3}$ \\ \& João ZILHÃO $3,4,5$
}

\begin{abstract}
Here we analyze the fossil remains of Castor fiber from the Middle Pleistocene site of Gruta da Aroeira, in the Almonda karst system, Tagus basin (Torres Novas, Portugal) and discuss the archaeological implications of the presence of beavers in the region. The Almonda karst system has been the backdrop for human evolution in Portugal, because there are different localities, of different ages, from the Middle Pleistocene to the Holocene, with fossil remains of hominins as well as faunal and archaeological remains Beaver fossils have been found in the archaeological deposits of at least three cavities of the karst system: the Gruta da Aroeira, the Gruta da Oliveira and the Galeria da Cisterna. Here, for the first time, we describe the fossils of Castor fiber from Gruta da Aroeira. The beavers from Aroeira are remarkable because they are the westernmost fossil record of Castor fiber in Europe dated to Marine Isotope Stage (MIS) 11, around $420 \mathrm{ka}$. The aim of the present article is twofold, firstly to study the fossils of beavers from the Aroeira locality, and secondly to discuss the palaeoecological and palaeoenvironmental implications of the presence of this rodent in the Almonda karst sites. This allows us to discuss the hominin-beaver interactions.
\end{abstract}

Keywords: fossil beavers, skull, mandible, teeth, archaeology, human-beaver interactions, Portugal

\section{RÉSUMÉ}

LES FOSSILES DE CASTOR FIBER DE GRUTA DA AROEIRA (PORTUGAL) ET L'INTÉRACTION ENTRE HUMAINS ET CASTORS

Ici, nous analysons les fossiles de Castor fiber du site Pléistocène moyen de Gruta da Aroeira, dans le système karstique de Almonda, bassin du Tage (Torres Novas, Portugal), et les implications archéologiques de la présence de castors dans la région. Le karst d'Almonda est un cadre de référence pour l'étude de l'évolution humaine dans la partie occidentale de l'Europe, du Pléistocène moyen à l'Holocène, avec aussi bien des restes d'hominidés fossiles, que de faunes et de vestiges archéologiques. Des fossiles de castors ont été trouvés dans les gisements archéologiques d'au moins trois cavités du système karstique : la Gruta da Aroeira, la Gruta da Oliveira et la Galeria da Cisterna. Ici, pour la première fois, nous décrivons les fossiles de Castor fiber de Gruta da Aroeira. Les castors d'Aroeira sont remarquables car ils sont la trace fossile la plus occidentale de Castor fiber en Europe; ils sont datés du Stade Isotopique Marin (MIS) 11, autour de $420 \mathrm{ka}$. Le but de cet article est double, d'une part de présenter l'évolution des castors à travers les fossiles d'Aroeira, et d'autre part de discuter des implications paléoécologiques et paléoenvironnementales de la présence de ce rongeur dans le karst d'Almonda. Cela nous permet de discuter des possibles interactions entre humains et castors.

Mots-clés : castors fossiles, archéologie, interactions humains-castors, Portugal

\section{1 - INTRODUCTION}

The Eurasian beaver, the species Castor fiber, is a large and semiaquatic rodent with a sparse fossil record. Since the emergence of the family Castoridae, during the Eocene, beavers were tiny to giant, and semiaquatic or burrowing rodents (Crusafont et al., 1948; Freye 1978; Aldana Carrasco, 1992; Hugueney \& Escuillie 1996; Meentemeyer et al., 1998; Hugueney, 1999). The family Castoridae was diverse during the Tertiary, but in the Quaternary only two genera of beavers survived in
Europe: the extinct Trogontherium (Fostowicz-Frelik, 2008) and the current genus Castor (Barisone et al., 2006).

The single extant genus, Castor, comprehends two species, the eurasiatic beaver, Castor fiber and the American beaver, Castor canadiensis. Fossils of the genus Castor are present in Eurasia since the late Miocene, $c a$. $10 \mathrm{Ma}$ (Aldana Carrasco, 1992; Hugueney, 1999).

The first record of beavers in the Iberian Peninsula occurs in Spain, in the late Pliocene fluvio-lacutrine layers of the Granada basin (García-Alix et al., 2007), while the first fossil representatives of the species

1 Aragosaurus-IUCA, Department of Earth Sciences, University of Zaragoza, calle Pedro Cerbuna, 12, ES-50009, Zaragoza. Email: cuencag@unizar.es

${ }^{2}$ Grup de Recerca del Quaternari (GRQ-SERP), Dept. d'Història i Arqueologia, Universitat de Barcelona, Carrer Montalegre, 6, ES-08001, Barcelona.

${ }^{3}$ Centro de Arqueologia da Universidade de Lisboa (UNIARQ), Faculdade de Letras de Lisboa, Universidade de Lisboa, Alameda da Universidade, PT-1600-214, Lisboa.

${ }^{4}$ Institució Catalana de Recerca i Estudis Avançats (ICREA), Passeig Lluís Companys 23, ES-08010 Barcelona.

${ }^{5}$ Universitat de Barcelona, Department d'Història i Arqueologia, Facultat de Geografia i Història, c/Montalegre 6, ES-08001, Barcelona. 


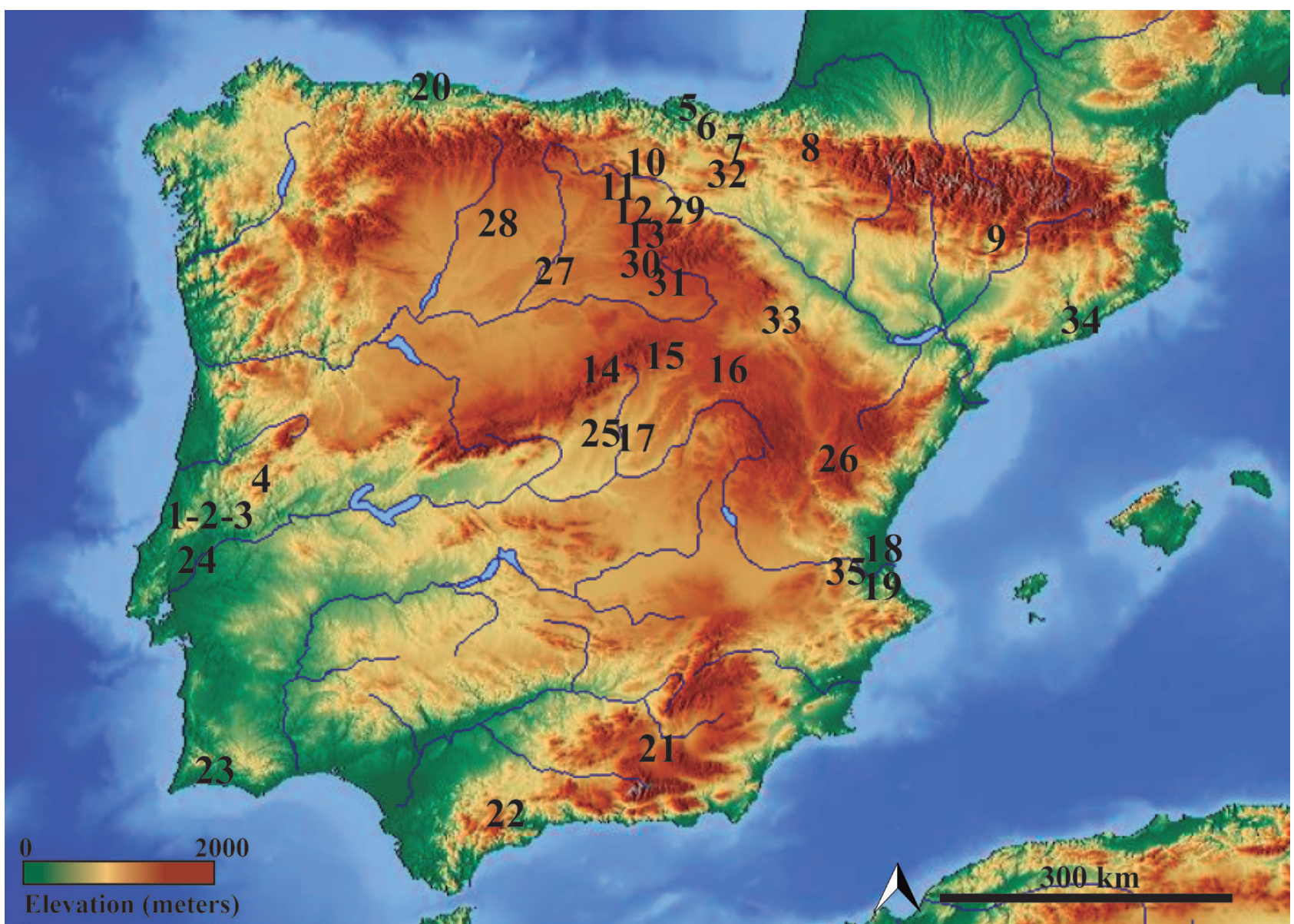

Fig. 1: Localities from the Iberian Peninsula with beaver remains.

Pleistocene localities: 1/ Gruta da Aroeira, 2/ Galeria da Cisterna, 3/ Gruta da Oliveira, 4/ Caldeirão, 5/ Arlanpe, 6/ Lezetxiki, 7/ Olazagutía, 8/ Zatoya, 9/Els Muricecs, 10/ La Blanca, 11/ Valdegoba, 12/ Atapuerca (Sima del Elefante and Gran Dolina), 13/ Cueva Millán, 14/ Pinilla del Valle, 15/ Cueva de las Figuras, 16/ Cueva de los Casares, 17/ Áridos I, 18/ Bolomor, 19/ Cova Negra, 20/ Las Hienas. Holocene localities: 21/ Cuesta del Negro, 22/ Ronda, 23/ Alcaria de Arge, 24/Vila Nova de São Pedro, 25/ Perales del Río, 26/ Sima del Ruidor, 27/ El Soto de Medinilla, 28/ Era Alta, 29/ Atapuerca (Portalón), 30/ Clunia, 31/ Ucero, 32/ La Peña, 33/ Bilbilis, 34/ Sant Pere de Gavà, 35/ Barranc Fondo. Map extracted from OpenStreetMap.

Fig. 1 : Sites de la Péninsule Ibérique avec fossiles de castor. Sites pléistocènes: 1/ Gruta da Aroeira, 2/ Galeria da Cisterna, 3/ Gruta da Oliveira, 4/Caldeirão, 5/ Arlanpe, 6/ Lezetxiki, 7/ Olazagutía, 8/Zatoya, 9/ Els Muricecs, 10/ La Blanca, 11/Valdegoba, 12/ Atapuerca (Sima del Elefante and Gran Dolina), 13/ Cueva Millán, 14/ Pinilla del Valle, 15/ Cueva de las Figuras, 16/ Cueva de los Casares, 17/ Aridos I, 18/ Bolomor, 19/ Cova Negra. 20/Las Hienas. Sites holocènes: 21/Cuesta del Negro, 22/Ronda, 23/Alcaria de Arge, 24/Vila Nova de São Pedro, 25/ Perales del Río, 26/ Sima del Ruidor, 27/El Soto de Medinilla, 28/Era Alta, 29/Atapuerca (Portalón), 30/Clunia, 31/Ucero, 32/La Peña, 33/ Bilbilis, 34/ Sant Pere de Gavà, 35/ Barranc Fondo. Carte extraite de OpenStreetMap.

Castor fiber appear in the Early Pleistocene levels of the Atapuerca site complex: "Trinchera-TE; TD", Sima del Elefante (level TE9, 1.2 Ma) and Gran Dolina (TD4TD6, 0.9-0.78 Ma) (Cuenca-Bescós et al., 1999, 2001, 2017) (fig. 1).

Here, we describe Castor fiber remains from Gruta da Aroeira, one of the scarce contexts in the Iberian Peninsula containig Acheulean-bearing hominins (Daura et al., 2017, 2018; López-García et al., 2018; Sanz et al., 2018, 2020). The site has yelded a rich assemblage of beaver remains dated to MIS 11, the earliest evidence of the species in Portugal. The aim of this paper is to provide the description of the beavers from Aroeira, and enable us to discuss the palaeoecological and palaeoenvironmental implications in relation to the human presence.

\section{2 - SITE DESCRIPTION}

Gruta da Aroeira $\left(39^{\circ} 30^{\prime} 20^{\prime \prime} \mathrm{N}, 08^{\circ} 36^{\prime} 57^{\prime \prime} \mathrm{W}\right)$ is a cave located in the Central Limestone Massif of Estremadura (municipality of Torres Novas, Santarém), in central
Portugal (fig. 2). It forms part of the Almonda karst system (fig. 2) (Zilhão et al., 1991, 1993; Daura et al., 2017, 2018). Fieldwork was first conducted in an area external to the site between 1997 and 2002, where erosion had already exposed the sediments of the cave (in the so-called Brecha das Lascas locus), and in the reopened cave entrance (Gruta da Aroeira). In the published studies of these initial excavations, Gruta da Aroeira was designated as "Galerias Pesadas" (Marks et al., 2002a,b; Trinkaus et al., 2003). Archaeological excavations resumed in 2013 in a $6 \mathrm{~m}^{2}$ area at the back of the cave (squares H-J/6-8) (fig. 2), with the aim of reaching the base of the stratigraphic succession, assess the depth of the archaeological sequence and determine its chronological range. In this area, the stratigraphic succession spans a thickness of $4 \mathrm{~m}$ and comprises three major units. The uppermost one, Unit 1 , is a brecciated infill capped by flowstone. Unit 2 (fig. 2) is a $2.2 \mathrm{~m}$-thick mud-supported breccia, rich in angular and subrounded clasts, corresponding to Acheulean layer $\mathrm{X}$ and capped by a second flowstone dated to $418+37 /-27 \mathrm{ka}$ $(2 \sigma)$. Layer $X$ is divided into sub-layers $X$ and $X b / c$ 

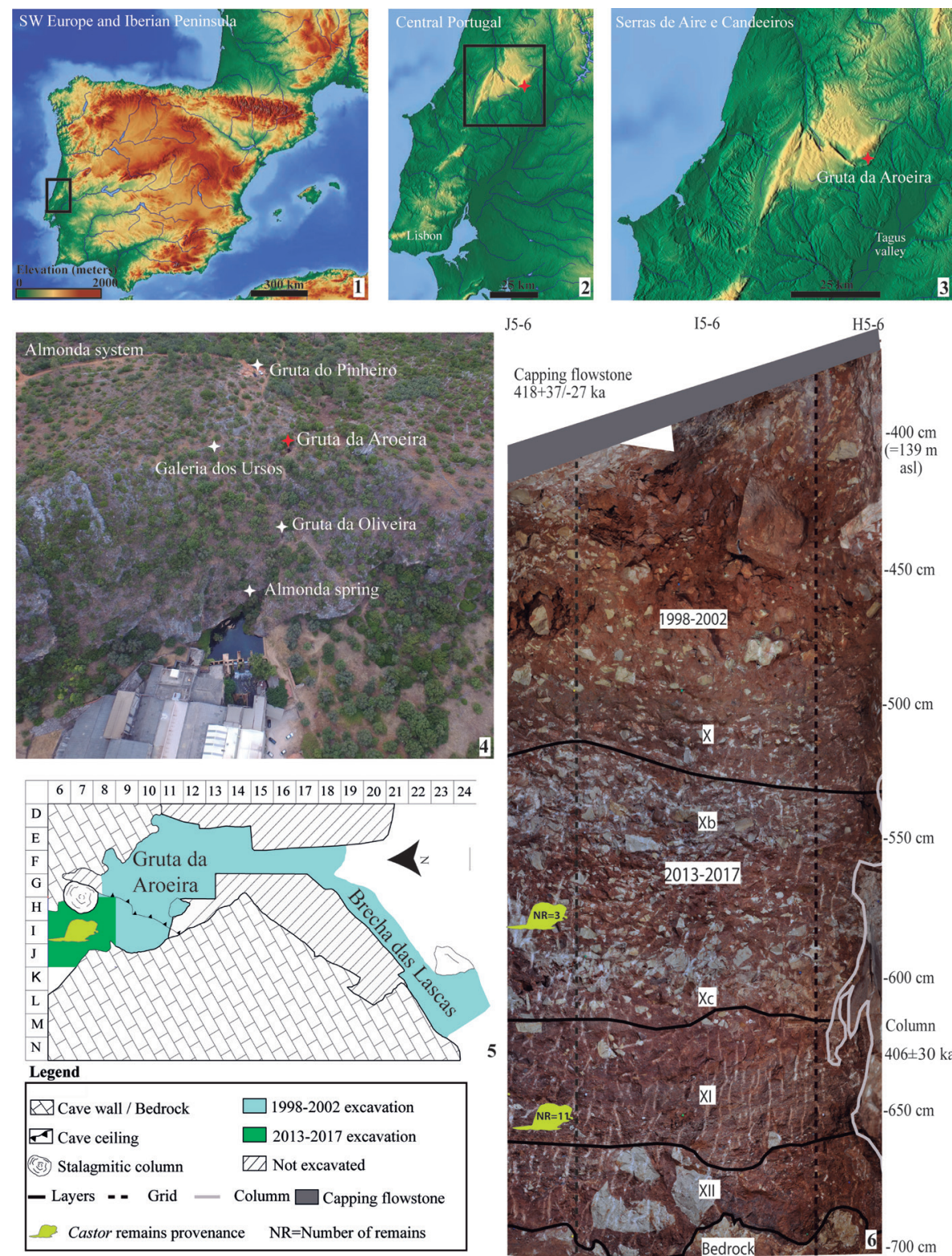

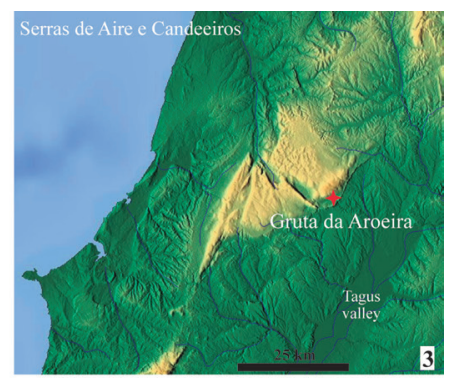

Fig. 2: The site.

(1-3) Geographical location of the Gruta da Aroeira site in the Central Limestone Massif of Estremadura (municipality of Torres Novas, Santarém), in central Portugal, Iberian Peninsula. The site is a cave forming part of the Almonda karst system, in the Tagus basin. Maps are extracted from OpenStreetMap. (4) The Almonda escarpment with the position of Aroeira and the other caves mentioned in the text (image from Pedro Souto). (5) Gruta da Aroeira plan and excavation grid. (6) Gruta da Aroeira stratigraphic profile. Layer $\mathrm{X}$ is divided into sublayers $X$ and $X b / c$ excavated between 1997-2002 and between 2013-2017. Fossils of beaver remains are signalled with the animal's silhouette. Note the flowstone capping the deposit containing the beaver remains.

Fig. 2: Le site. (1-3) Situation géographique de la Gruta da Aroeira dans le massif calcaire central d'Estremadura (commune de Torres Novas, Santarém), au centre du Portugal, péninsule ibérique. Le site est une grotte faisant partie du système karstique d'Almonda, dans le bassin du Tage. (4) L'escarpement de Almonda avec la position de Aroeira (image de Pedro Souto) et des autres grottes mentionnées dans le texte. (5) Plan de Gruta da Aroeira et carroyage. (6) Profil stratigraphique de Gruta da Aroeira. La couche $X$ est divisée en sous-couches $X$ et Xb/c fouilées entre 1997-2002 et entre 2013-2017. Les fossiles de castor sont signalés par la silhouette de l'animal. Remarquez la croûte stalagmitique qui scelle le dépôt où les restes de castor ont été trouvés. (corresponding to the upper and lower parts of a single unit, excavated between 1997-2002 and 2013-2017, respectively). This layer has provided significant evidence about the Acheulean-bearing hominins of Europe, such as the human cranium Aroeira 3, burned bones and other faunal remains, lithic artefacts, including handaxes, and a Cercopitecid mandible (Daura et al., 2017, 2018; CondeValverde et al., 2018; López-García et al., 2018; Sanz et al., 2018, 2020; Alba et al., 2019).

The basal unit, Unit 3, is a fluvial deposit of endokarst origin comprising two layers: layer XI is a $0.4 \mathrm{~m}$-thick silty sand with scattered gravel and faunal remains but no artefacts, and layer XII is a $0.5 \mathrm{~m}$-thick, archaeologically sterile, slightly gravelly sand. The external layer of a stalagmite column covered by layer XII has been dated to $406 \pm 30 \mathrm{ka}(2 \sigma)$, giving a maximum age for layer $\mathrm{X}$ and part of layer XI, whose deposition, therefore, can be placed within the 390-436 ka interval. Both layers thus date to MIS 11. The fossil remains of Castor fiber described here were recovered during the fieldwork carried out at the site between 2013 and 2017. Most were found in layer $\mathrm{XI}$; a few come from layer $\mathrm{X}(\mathrm{Xb})$.
Beaver remains of a younger chronology have also been recovered in other sites of the Almonda karst system: in Late Pleistocene layer 13 of Gruta da Oliveira (Zilhão et al., 2010), and in layer C of the AMD2 locus of Galeria da Cisterna, a fluvial deposit of Tardiglacial age (Antunes, 1989; Zilhão et al., 1991, 1993; Zilhão, 2009, 2016; Trinkaus et al., 2011).

\section{3 - MATERIAL AND METHODS}

\section{1 - EXCAVATION METHODS}

The fossil remains of Castor fiber were recovered in layers $\mathrm{XI}(\mathrm{NR}=13)$ and $\mathrm{X}(\mathrm{NR}=3)$ of the Gruta da Aroeira. The fossils were completely encased in hard carbonate breccias. The hard material needed to be excavated at the site, using a demolition hammer. The bones were removed in blocks and transported to the laboratory. The fossil bones were detached using a pneumatic microhammer and microchisel (Mod. CTS 178) and restored using a normal air scribe (Mod. W224). Where necessary, bones 
were consolidated with an acrylic resin (Paraloïd-B72) dissolved in acetone $\left(\mathrm{C}_{3} \mathrm{H}_{6} \mathrm{O}\right)$. Some fossil remains are still undergoing restoration. Washing and sieving of the sediments are a common method to recover fossil microvertebrates. However, given the size of beavers, their fossil bones were retrieved in the course of the archaeological excavation work, not during the washingsieving of the sediments. A study of the microvertebrates from washing and sieving the sediments from Aroeira can be found in Lopez-García et al. (2018).

\section{2 - ANATOMICAL TERMS}

The terms and parameters used in the descriptions of Castoridae are from Repenning (1968), Hugueney (1999), Barisone et al. (2006), Korth (2008), FostowiczFrelik (2008), Mörs \& Stefen (2010), and Cuenca-Bescós et al. (2017). The premolars and molars have folds on the lingual and labial sides which are named striids for lower, and striae for upper cheek teeth, following Crusafont et al. (1948) and Van de Weerd (1976). The folds become the flexids for the lower and flexae for the upper cheek teeth in the occlusal surface. The isolated enamel islets on the occlusal surface of older individuals are described as fossettids in the lower and fossettes in the upper cheek teeth. A distinction between beavers and porcupines (Family Hystricidae, Genus Hystrix) is that the enamel islets are formed early in the ontogeny of the porcupines, whereas in beavers they are formed later and do not appear until the animals are old. In the Castoridae, the striae and striids usually reach the base of the crown, while in the Hystricidae they are shorter.

\section{3 - MEASUREMENTS}

The measurements of the mandible are: height, from the tip of the digastric eminence to the most mesial alveolar edge of the chewing teeth; total alveolar length; and length of the diastema. The mesio distal length and labio lingual width of the incisor and cheek teeth were taken in the occlusal surface. Measurements were taken with a Mitutoyo digital caliper (model CD-8"CX). Given the large size of some specimens, they were photographed with a digital camera Nikon Coolpix 3100 and then measured again. A scale was photographed for referencing. Measurements are given in $\mathrm{mm}$.

\section{4 - ABBREVIATIONS}

The letters I, P, M, in capital letters are for the upper dentition, incisor, premolar and molar respectively. Lower case letters (i, p, m) are for the lower dentition; $\mathrm{md}$, mandible. $\mathrm{L}, \mathrm{W}$ are the maximum length and width of the anatomical elements measured. TD or TE are the localities of the Atapuerca karst system where T means trench or "Trinchera" in Spanish; MIS, Marine Isotopic Stage; ka, kiloannum.

\section{5 - HOUSING OF THE MATERIAL}

The archaeozoological material from Aroeira is currently housed at the Centro de Arqueologia da Universidade de Lisboa (UNIARQ) in Lisbon, Portugal. The remains are labelled using the site acronym ARO followed by the inventory number.

\section{4 - RESULTS: SYSTEMATIC PALAEONTOLOGY}

Order RODENTIA Bowdich, 1821

Family CASTORIDAE Hemprich, 1820

Genus Castor Linnaeus, 1758

The physical appearance of the two species, Castor fiber and $C$. canadensis is comparable, but their karyotypes make them separate species (Ducroz et al., 2005).

Species Castor fiber Linnaeus, 1758

\section{STUDIED SPECIMENS}

The studied specimens of Castor fiber from layers X and XI are: right mandible with the complete tooth row, $\mathrm{i}$ to $\mathrm{m} 3$ (ARO \#682); left mandible with i, p4, $\mathrm{m} 1$ and $\mathrm{m} 2$ and isolated M1-2 (ARO \#740); right maxillary fragment (ARO \#131); right maxilla P4 to M3 (ARO \#158); right maxilla I-P4 (ARO \#663); left maxilla I-M1 (ARO \#173); isolated P4 and M1 (ARO \#171); metapodial (ARO \#665); and cemented bones, formed by humerus, radius, ulna, rib, femur and pelvis (ARO \#677). The studied specimens of Castor fiber from layer $\mathrm{Xb}$ are: left maxilla with P4 to M3 (ARO \#1299); left mandible i-m1 (ARO \#930); and left scapula (ARO \#1220).

\section{MANDIBLE}

There are seven mandibular fragments in layers XI and X from Gruta da Aroeira (pl. 1). The mandible is robust, the articular condyle is large (pl. 1, cls. $1 \mathrm{~b} \& 1 \mathrm{c}$ ). The mandible has a strong digastric eminence, seen in the ventral part in both lateral and medial views (pl. 1, cls 4a $\& 4 b$ ); the anterior part of fma is between the alveoulus of the $\mathrm{p} 4$ and $\mathrm{m} 1$. The upper maseteric crest is prominent. In broken mandibles, the long alveolus of the incisor is visible (pl. 1, cls 1c, 2a \& 3b).

\section{THE INCISOR}

The lower incisor is a long tooth of continuous growth and never develops roots. The long alveolus extends distally into the vertical ramus of the mandible, behind the alveolus of the $\mathrm{m} 3$ (pl. 1, cls. 1c, 2a \& 4b). The labio lingual width of the incisor varies sligthy along the tooth decreasing to the base, as shown in the table 1 measurement of $i \# 682$.

\section{THE CHEEK TEETH, P4, M1, M2, M3}

All the teeth present the typical striids of lower cheek teeth in the genus Castor in the labial and lingual sides 


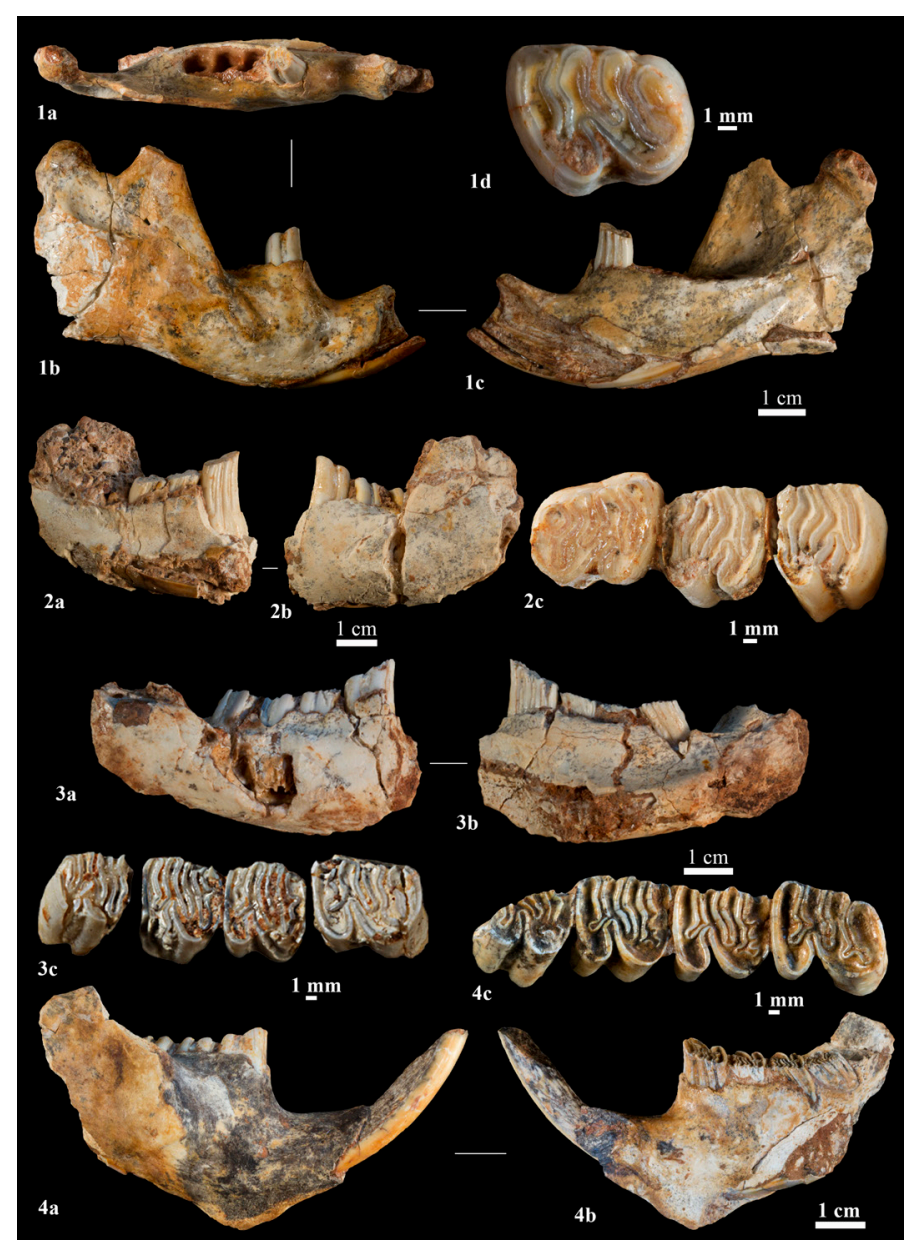

Pl. 1: Castor fiber mandibles, with their preserved teeth: premolar (p) and molars (m), from Aroeira.

(1) Right mandible (ARO\#633), in (1a) occlusal, (1b) latera and (1c) medial views; (1d) occlusal view of the only tooth preserved, the p4. (2) Left mandible (ARO\#740) in (2a) medial and (2b) lateral views; (2c) occlusal view of p4- m2. (3) Right mandible (ARO\#158) in (3a) lateral and (3b) medial views (3c) occlusal view of p4-m3. (4) Right mandible (ARO\#682) in (4a) lateral and (4b) medial views; (4c) occlusal view of p4-m3. Pl. 1: Mandibules de Castor fiber, avec leurs dents conservées. prémolaires (p) et molaires ( $m$ ), d'Aroeira. (1) Mandibule droite (ARO \# 633), en vues (1a) occlusale, (1b) latérale et (1c) médiale (1d) vue occlusale de la seule dent conservée, la p4. (2) Mandibule gauche (ARO \# 740) en vue (2a) médiale et (2b) latérale; (2c) vue occlusale de p4- m2. (3) Mandibule droite (ARO \# 158) en vues (3a) latérale et ( $3 b)$ médiale: $(3 c)$ vue occlusale de $p 4$ m3. (4) Mandibule droite (ARO \# 682) en vues (4a) latérale et (4b) médiale; (4c) vue occlusale de p4-m3.

Tab. 1: Mandibular specimens and measurements of the fossil beaver remains, Castor fiber, from Aroeira.

Lower case letters are used for the lower dentition: i, incisor; $\mathrm{p} 4$ fourth premolar, $\mathrm{m} 1$, first molar; $\mathrm{m} 2$, second molar; $\mathrm{m} 3$, third molar; $\approx$ almost equal to; two values separated by - means that the same parameter was measured in different areas, usually anteriorposterior. Measurements are given in $\mathrm{mm}$.

Tab. 1: Spécimens mandibulaires et mesures de restes de castor fossile d'Aroeira, Castor fiber. Des minuscules sont utilisées pour la dentition inférieure: $i$, incisive; $p 4$, quatrième prémolaire, $m 1$. première molaire; $m 2$, deuxième molaire; $m 3$, troisième molaire,

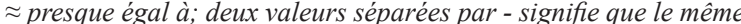
paramètre a été mesuré dans différentes zones, généralement antérieur-postérieur. Les mesures sont données en mm.

\begin{tabular}{|c|c|c|c|c|c|c|}
\hline Specimen ID & $\begin{array}{c}\text { Anatomical } \\
\text { location }\end{array}$ & $\begin{array}{c}\text { Mandibular elements } \\
\text { preserved }\end{array}$ & Length & Width & $\begin{array}{l}\text { Higth at alveolus } \\
\mathrm{p} 4\end{array}$ & Higth end diastema \\
\hline \multirow{3}{*}{ \# 663 AR02014 XI-16 } & \multirow{3}{*}{ Rigth } & Nearly complete & 92.66 & 17.03 & & \\
\hline & & i & 6.58 & 8.96 & & \\
\hline & & p4 & 7.51 & 7.04 & & \\
\hline \multirow{6}{*}{ \# 682 AR02014 XI-16 } & \multirow{6}{*}{ Rigth } & Horizontal ramus & & 17.45 & 28.47 & 25.68 \\
\hline & & i & 7.93 & $7.72-8.53$ & & \\
\hline & & p4 & 9.84 & 7.82 & & \\
\hline & & $\mathrm{m} 1$ & 8.52 & $\approx 8.19$ & & \\
\hline & & $\mathrm{m} 2$ & 8.09 & 7.62 & & \\
\hline & & m3 & 7.84 & $\approx 5.48$ & & \\
\hline \multirow{5}{*}{ \# 158 AR02014 XI-17 adult } & \multirow{5}{*}{ Rigth } & Horizontal ramus & $\approx 65.49$ & 18.93 & & \\
\hline & & p4 & 10.82 & 7.31 & & \\
\hline & & $\mathrm{m} 1$ & 8.12 & 7.35 & & \\
\hline & & $\mathrm{m} 2$ & 7.75 & 7.99 & & \\
\hline & & $\mathrm{m3}$ & 8.16 & 6.7 & & \\
\hline \multirow{4}{*}{ \# 928 AR02014 XI-17 } & \multirow{4}{*}{ Rigth } & Horizontal ramus & & & & \\
\hline & & $\mathrm{p} 4$ & $\begin{array}{c}\text { partially encased by } \\
\text { carbonate }\end{array}$ & & & \\
\hline & & $\mathrm{m} 1$ & & & & \\
\hline & & m2infd & idem & 8.25 & & \\
\hline \# 665 AR02014 XI-16 & Left & Fragmen alveolus and $\mathrm{i}$ & & $\approx 9.01$ & & \\
\hline \multirow{5}{*}{ \# 740 ARO 2014 XI-16 } & \multirow{5}{*}{ Left } & Horizontal ramus & & 16.85 & & \\
\hline & & i & & 6.9 & & \\
\hline & & p4 & 8.95 & 7.02 & & \\
\hline & & $\mathrm{m} 1$ & 8.53 & 7.75 & & \\
\hline & & $\mathrm{m} 2$ & 6.72 & 8.6 & & \\
\hline \multirow{4}{*}{ \# 930 ARO 2014 Xb-h6 } & \multirow{4}{*}{ Left } & Horizontal ramus & 51.84 & 16.97 & 28.91 & \\
\hline & & i & 7.75 & 8.64 & $9.77-8.65$ & \\
\hline & & p4 & 11.32 & 8.86 & & \\
\hline & & $\mathrm{m} 1$ & 9.93 & 8.51 & & \\
\hline
\end{tabular}




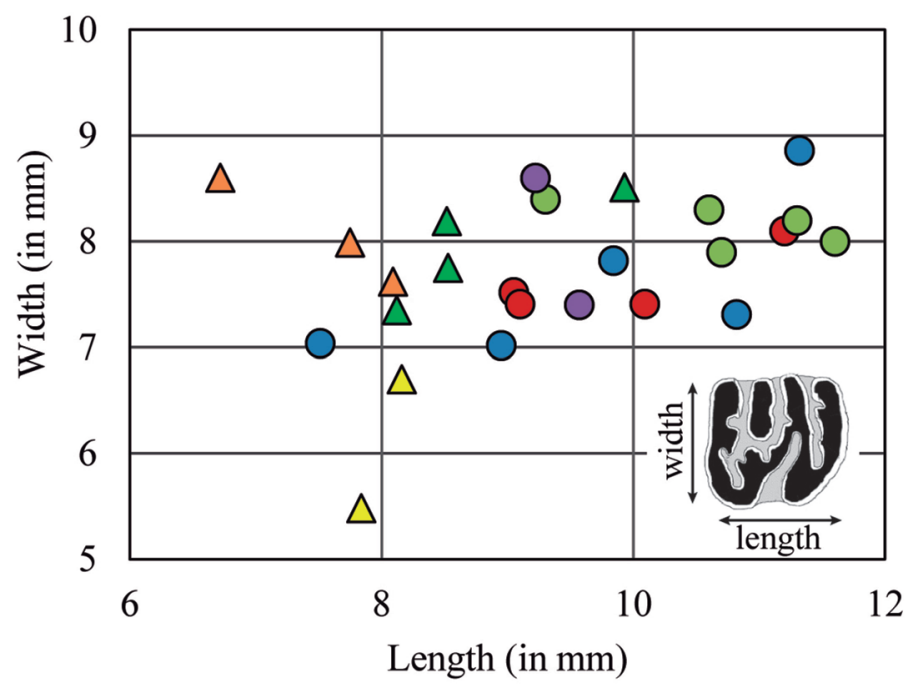

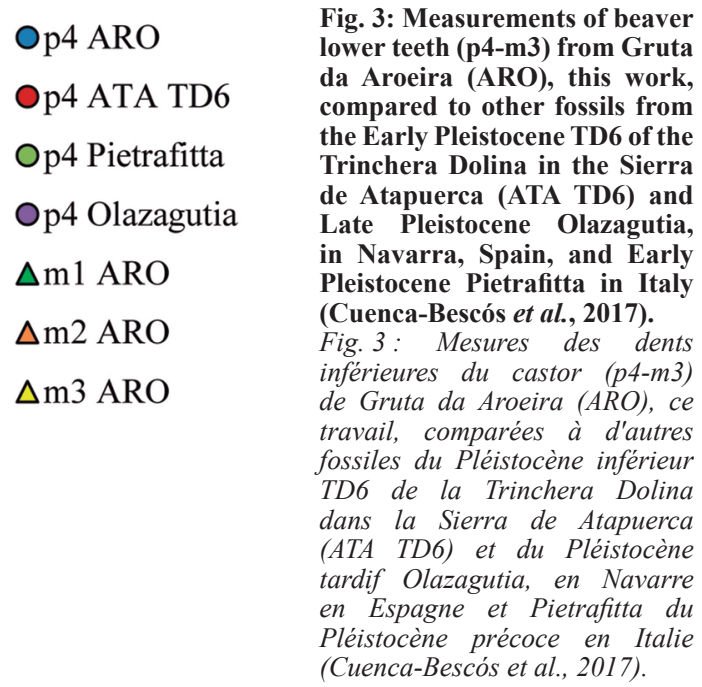

(pl. 1, cls. 1a, 1b, 1c, 2a, 2b, 3a, 3b, 4a \& 4b). The oclusal surfaces present also the typical folds or flexids of beaver molars (pl 1., cls. 1d, 2c, 3c \& 4c). The p4, m1, $\mathrm{m} 2$ and $\mathrm{m} 3$ of mandible ARO \#682 present a noticeable crenulated paraflexid, unfolding in two or more folds on its anterior side (pl. 1, cl. 4c). The flexids of the premolars and molars in the rest of specimens are smooth. The fossettids in the p4 of mandible ARO \#158 (pl. 1, cls. 3a $\& 3 \mathrm{c}$ ), shows that it is a senile beaver. The rest of the mandibles have cheek teeth of juvenile to young adult beavers, not reaching the "fossetid" stage. The size of the teeth is given in table 1 . Note the great variability of the length (L) of the $\mathrm{p} 4$, while the width $(\mathrm{W})$ is less variable (fig. 3). Some cheek teeth lack fragments of enamel; in the tables, the symbol $\approx$ indicates that the parameter may be a bit larger than the measurement obtained because the enamel wall is damaged.

\section{MAXILLAE}

Fragments with teeth as well as isolated upper teeth are the only maxillary remains (pl. $2 \&$ tab. 2). The cheek teeth have the striae and folds tipical of Castor fiber.

\section{POSTCRANIAL REMAINS}

The postcranial remains of Castor fiber are mostly incomplete (pl. 3). From layer XI, the remains are: the proximal articulation and part of the shaft of a right humerus (ARO \#677; 40.01x23.65x16.59; pl. 3); part of the ilium and acetabulum of the left pelvis $(22.95 \times 16.12)$. There are also several fragments of ulna, radio and autopodials. From layer $\mathrm{Xb}$, the remain is a fragment of the left scapula (ARO\#1220; 96.33×60.41×6.53; pl. 3).

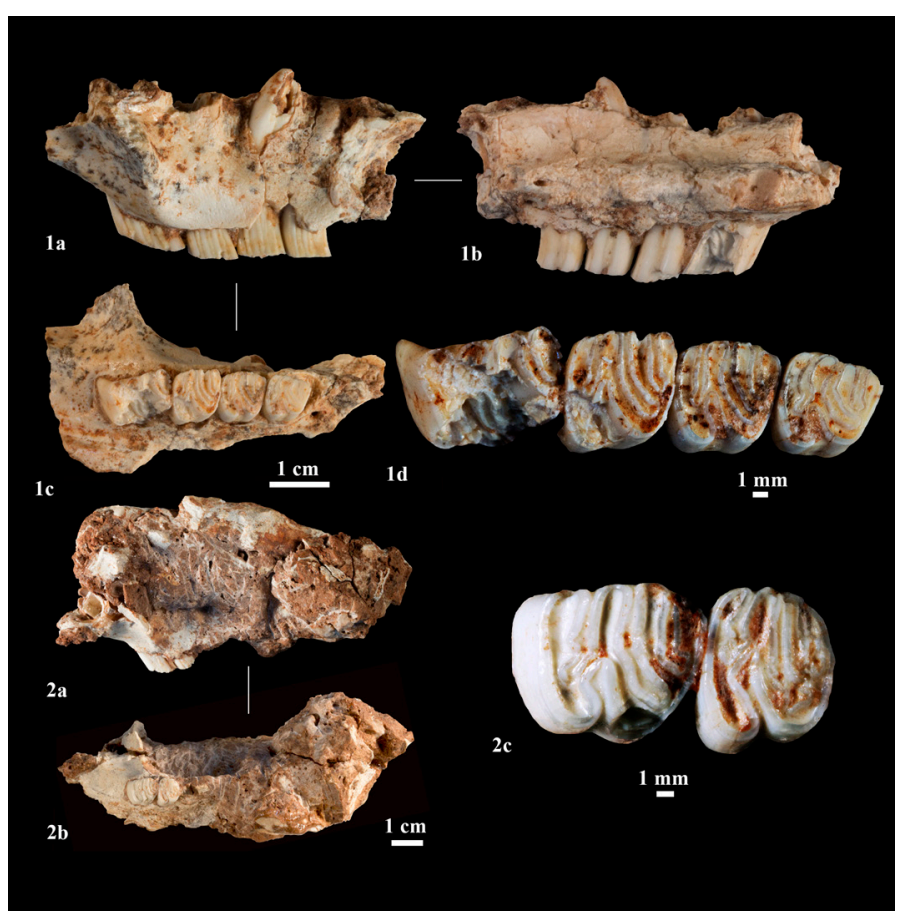

Pl. 2: Fragments of Castor fiber maxillae with their preserved teeth: premolar $(\mathrm{P})$ and molars $(\mathrm{M})$, from Aroeira.

(1) Left maxilla (ARO\#1299) in (1a) lateral, (1b) medial and (1c) occlusal views; (1d) occlusal view of P4-M3. (2) Left maxilla (ARO\#173) in (2a) medial and (2b) occlusal views; (2c) occlusal view of M1-P4 (2c).

Pl. 2: Fragments de maxillaires de Castor fiber avec leurs dents conservées: prémolaires $(P)$ et molaires $(M)$, d'Aroeira. (1) Maxillaire gauche (ARO \# 1299) en vues (1a) latérale, (1c) médiale et (1c) occlusale; (1c) vue occlusale du P4-M3. (2) Maxillaire gauche (ARO \# 173) en vues (2a) médiale et (2b) occlusale ; (2c) vue occlusale de M1-P4. 


\begin{tabular}{|c|c|c|c|c|}
\hline Specimen ID & Element and side & $\begin{array}{l}\text { Upper dentition } \\
\text { preserved }\end{array}$ & Length & Width \\
\hline ARO \#740 & Rigth & M1-2 & 6.09 & 6.49 \\
\hline \multirow{3}{*}{ ARO \#173 } & \multirow{3}{*}{ Left maxilla } & I & 9.16 & 8.4 \\
\hline & & P4 & 9.36 & 7.81 \\
\hline & & M1 & 6.78 & 8.24 \\
\hline \multirow{2}{*}{ ARO \#171 } & \multirow{2}{*}{ Left maxilla } & P4 & 8.91 & 8.08 \\
\hline & & M1 & 6.08 & 5.62 \\
\hline \multirow{2}{*}{ ARO \#173 } & \multirow{2}{*}{ Rigth maxilla } & P4 & 9.93 & 0.34 \\
\hline & & M1 & 7.42 & 8.45 \\
\hline ARO \#188 & Rigth maxilla & M1-2 & 6.67 & 6.44 \\
\hline ARO \#666 & Rigth maxilla & M1-2 & 6.09 & 6.11 \\
\hline \multirow{4}{*}{ ARO \#1299 } & \multirow{4}{*}{ Left maxilla } & P4 & 8.67 & 8.72 \\
\hline & & M1 & 6.87 & 6.8 \\
\hline & & $\mathrm{M} 2$ & 6.08 & 6.25 \\
\hline & & M3 & 5.88 & 6.15 \\
\hline
\end{tabular}

Tab. 2: Maxillary specimens and measurements of Aroeira fossil beaver remains, Castor fiber. Upper case letters are used for the upper dentition: $\mathrm{I}$, incisor; $\mathrm{p} 4$, fourth premolar, $\mathrm{m} 1$, first molar; $\mathrm{m} 2$, second molar; $\mathrm{m} 3$, third molar. Measurements are given in $\mathrm{mm}$.

Tab. 2 : Mesures des restes de maxillaire de castor fossile d'Aroeira, Castor fiber. Les majuscules sont utilisées pour la dentition supérieure: I, incisive; $p 4$, quatrième prémolaire, $m 1$, première molaire; $m 2$, deuxième molaire; $m 3$, troisième molaire. Les mesures sont données en $\mathrm{mm}$.

\section{5 - DISCUSSION}

The dimensions and morphology of the Castor fiber from Aroeira are not significantly different from Quaternary specimens of Castor fiber and extant beavers. Still, the ARO-p4 is slightly shorter and narrower than the p4 of the beavers from the Early Pleistocene of Pietrafitta and Atapuerca Gran Dolina TD6, and the Late Pleistocene from Olazagutia (Cuenca-Bescós et al., 2017). We use the $\mathrm{p} 4$ because this tooth is the most complete element in the ARO material, as well as in the other collections and so a sufficient sample can be gleaned from the literature. The smaller dimensions are related to the fact that most Aroeira specimens are juvenile; hence, it is to be expected that their size be somewhat smaller (Stefen, 2009).

In the Iberian Peninsula, Castor fiber persists until the Late Pleistocene and the Early Holocene (Sesé \& Soto, 1981, Villaverde \& Martí, 1984; Antunes, 1989; Zilhão et al., 1991, 1993; Póvoas et al., 1992). Its last appearance datum may correspond to the Late Prehistory to Roman ages at: the Vila Nova de São Pedro hilltop settlement, in the Ribatejo (Antunes, 1989); El Soto de Medinilla (Liesau von Lettow-Vorbeck, 1998), in Valladolid, and El Portalón de Cueva Mayor in Atapuerca (Cuenca-Bescós et al., 2017).

\section{1 - TAPHONOMY AND DEMOGRAPHIC COMPOSITION}

Most of the mandibular specimens are juveniles or young adults. They present unerupted or recently erupted incisors and the fossetid condition is not present. Compared with the data in Stefen (2009), the length of Aroeira's p4 suggests that they belong to animals of between two and four years of age (25-50 months). The proportion of juveniles to adults is $6 / 1$. Juvenile beavers

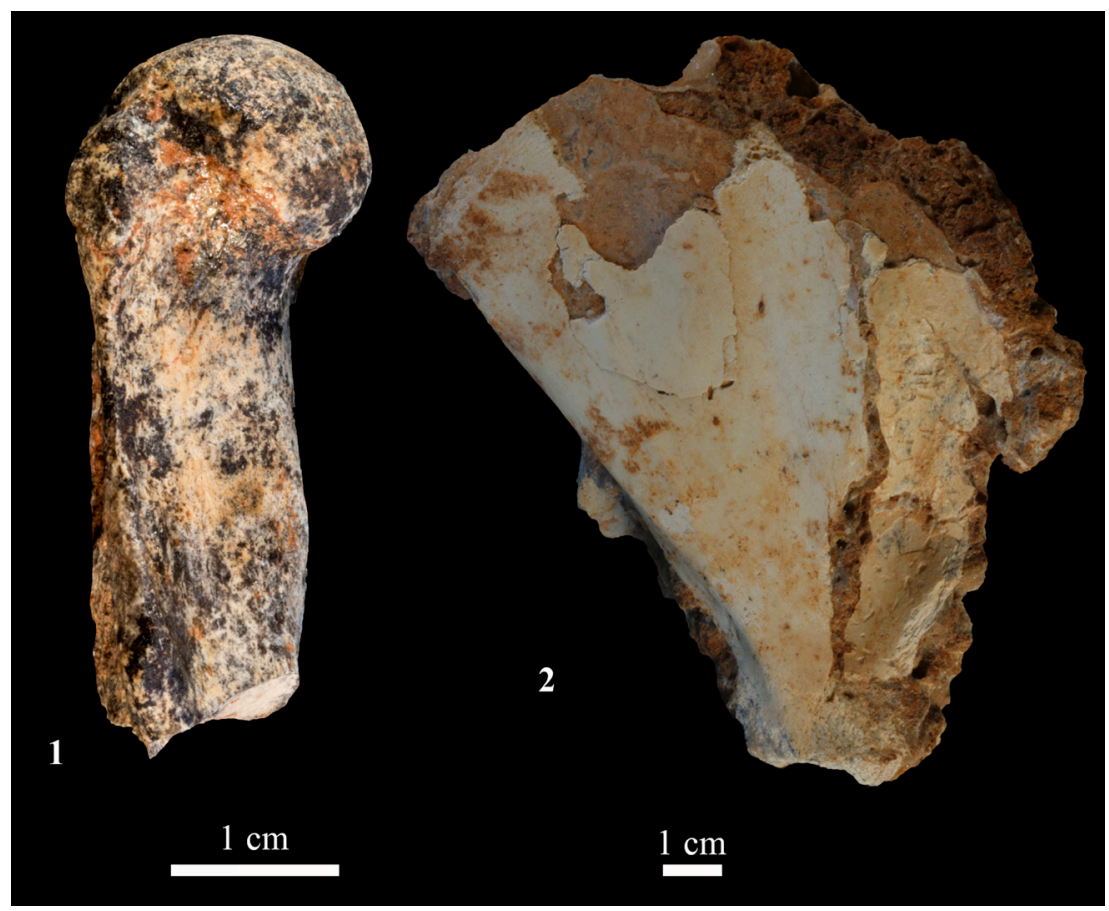

PI. 3: Castor fiber postcranial remains from Gruta da Aroeria.

(1) Left humerus, proximal articulation and shaft in lateral-posterior view (ARO \#677) from layer XI. (2) Scapula (ARO \#1220) from layer $\mathrm{Xb}$.

Pl. 3: Restes postcrâniens de Castor fiber de Gruta da Aroeira. (1) Humérus gauche, articulation proximale et diaphyse en vue latérale-postérieure (ARO \# 677) de la couche XI. (2) Omoplate (ARO \# 1220) de la couche Xb. 
usually leave the family pond after the second year; as a rule, therefore, the family group includes more juveniles than adults (Halley \& Rosell, 2002, 2003; Halley, 2011, Campbell-Palmer et al., 2012; Halley et al., 2013). Thus, the composition of Aroeira's Castor fiber thanatocenosis is consistent with a natural accumulation.

No direct carnivore or anthropogenic modification of these bones could be identified. Even though beaver remains are scarce in Lower Palaeolithic sites, the exploitation of this taxon by hominins has been demonstrated in two layers from Caune de l'Arago, where the practice was deemed opportunistic but not rare (Lebreton et al., 2017). In the Middle and Upper Palaeolithic, the evidence that beavers were hunted for their fur and meat is more abundant (Fiore et al., 2004; Slimak et al., 2010; Rendu, 2010). Given that Aroeira layer XI is a fluviatile deposit and the beaver bones found therein show no evidence of anthropogenic modification, it is likely that, as with the remains from layer $\mathrm{C}$ of Galeria da Cisterna, they relate to natural death events.

However, in layer X of Gruta da Aroeira and layer 13 of Gruta da Oliveira, the Castor fiber fossil remains come from archaeological deposits in which they are found in association with the remains of hunted game and abundant stone tools of, respectively, Acheulean and Mousterian affinities. These deposits accumulated once the incision of the underground network and the descent of the phreatic level in the system turned those former karst outlets into open cave entrances available for human occupation; in these cases, the beaver remains were not found in deposits that reflect their natural environment. Therefore, whatever the cause of the animals' deaths - natural or inflicted by a predator - an agent of accumulation must have been involved in the transportation of the carcasses, or elements thereof, from the ponds at spring level to the cave entrances located upslope. In the case of Gruta da Oliveira, coeval use of the site by hyaenas and other carnivores means that an agent other than humans may have been responsible for the beaver remains. In the case of Gruta da Aroeira, however, bear is the only carnivore (scarcely) represented, the faunal assemblage is dominated by anthropogenically accumulated ungulate remains, and so it remains entirely possible that the layer $\mathrm{X}$ beavers reflect human hunting of the species, as at the Caune de l'Arago.

\section{2 - THE ECOLOGY AND HABITAT OF CASTOR FIBER IN AROEIRA}

Beavers are specialized mammals with strict ecological preferences - aquatic environments surrounded by abundant arboreal vegetation - and that seems to have been the case in the past as well (Hugueney, 2004; Barisone et al., 2006; Erbajeva \& Alexeeva, 2014). The habitat of Castor fiber is a mix of running and still water. Although European beavers seem to thrive in small rivers, living in shelters constructed along the banks, they can also make big dams. A good habitat for beavers should have perennial running water, be surrounded by forests to secure the supply of food and of wood for shelters and dams. The forests afford an easy access to food during winter seasons and provide the necessary timber for the building of dams, providing ponds that protected them against predators (CampbellPalmer et al., 2012, Perfect et al., 2014). These conditions require a regular rainfall and temperate climate, which agrees well with the formation time, MIS 11, of Aroeira layers $\mathrm{X}$ and $\mathrm{XI}$.

In recent times, the spring of the Almonda has been dammed to take advantage of its abundant and permanent water source to power watermills and to generate electricity for adjacent factories. The pond thereby formed provides a good analogy for the kind of environment that beavers could have created for themselves during the Quaternary. The animals would have been able to swim between the pond and the underground parts of the river upstream from the spring, explaining why their remains have been found in the basal, river-accumulated sands forming the base of the Aroeira and Cisterna sequences.

\section{3 - HUMANS AND BEAVERS}

Reduced to about 1200 animals in eight isolated populations by the beginning of the $\mathrm{xx}^{\text {th }}$ century, Castor fiber has recovered strongly in geographical range, populations, and number of individuals. By 2010, stable populations existed in all countries within their former natural range in Europe, except for Portugal, Italy and the southern Balkans. Until recently, it was held that beavers had gone extinct before historical times in many areas of their former natural range in Europe; though recent archaeological discoveries demontrate that beavers persisted until at least the Middle Age (Bejenaru et al., 2013; Manning et al., 2014; Salari et al., 2020 ). There is a growing body of literature on the importance of beavers as keystone species and ecosystem engineers (Zavyalov, 2014).

The archaeological evidence from the Almonda karst sites shows that beavers and humans shared the same area and environments from the Middle Pleistocene to the Late Pleistocene. As a line of thought, it is possible that humans in Aroeira used the ponds of Castor fiber for fishery. To date, no fish remains have been recovered in Gruta da Aroeira and the water birds recovered were not hunted (Marks et al., 2002a). However, fish remains are abundant in the Upper Magdalenian levels of Lapa dos Coelhos, another of the Almonda karst system sites, and the anthropogenic nature of those remains is corroborated by the bone fishhooks found alongside (Almeida et al., 2004).

There is increasing evidence for the consumption of semiaquatic and small game in the Palaeolithic. The data are scarce for the Lower Palaeolithic, and concern the consumption of tortoises, lagomorphs, marmots, and beavers (Desclaux et al., 2011; Blasco et al., 2016; Lebreton et al., 2017), but abundant documentation exists for the Middle and the Upper Palaeolithic (Stiner et al., 1999). In Portugal, the cave site of Figueira Brava demonstrates the large-scale exploitation of marine resources by Last Interglacial Neanderthals, including large crabs, mollusks, waterfowl and fish (Zilhão et al., 2020). There is little question that aquatic and semiaquatic resources played a role in the diet of Palaeolithic huntergatherers. 


\section{6 - CONCLUSIONS}

Beavers are poorly documented in the Iberian Lower Palaeolithic fossil record. Gruta da Aroeira is one of the few localities where several individuals are represented; the remains date to MIS 11 and are the earliest evidence of beavers in Portugal. Beaver populations expanded during the Upper Pleistocene in the Iberian Peninsula, when their fossils occur more frequently. Their presence in the Atlantic façade of Iberia during the Middle Pleistocene strengthens the notion that, in the past, the peninsula harboured important, well-established populations of beavers.

Indeed, the archaeological evidence strongly suggests that beavers were continuously present in the area around the Almonda spring through the Middle and the Late Pleistocene.

\section{ACKNOWLEDGMENTS}

Fieldwork was funded by the Câmara Municipal de Torres Novas with logistical support from Fábrica de Papel A Renova. This research was supported by the following projects: PTDC/HIS-ARQ/098164/2008 and PTDC/HAR-ARQ/30413/2017, funded by FCT (Fundação para a Ciência e a Tecnologia, Portugal), "Els canvis climàtics durant el plistocè superior a la costa central catalana i l'impacte en les poblacions neandertals i humans anatòmicament moderns (CLT009/18/00022 Direcció General del Patrimoni Cultural, Generalitat de Catalunya)", 2017SGR-00011 (Generalitat de Catalunya) and HAR2017-86509 (Spanish Government). M. Sanz was supported by a Juan de la Cierva postdoctoral grant (IJCI-2017-33908) and J. Daura by a Ramon y Cajal contract (RYC-2015-17667). We thank also to Ramon Álvarez (UB) for photographic documentation of beaver remains and Almudena Yagüe for restoring the specimens. Comparisons with the fossils from Atapuerca are thanks to project 4167645- PGC2018-093925-B-C33.

\section{REFERENCES}

ALDANA CARRASCO E.J. 1992 - Los Castoridae (Rodentia, Mammalia) del Neógeno de Catalulia (España). Treballs del Museu de Geologia de Barcelona, 2, 99-141.

ALBA D.M., DAURA J., SANZ M., SANTOS E., YAGÜE A.S., DELSON E. \& ZILHÃO J., 2019 - New macaque remains from the Middle Pleistocene of Gruta da Aroeira (Almonda karst system, Portugal). Journal of Human Evolution, 131, 40-47.

ALMEIDA F., ANGELUCCI D.E., GAMEIRO C., CORREIA J. \& PEREIRA T., 2004 - Novos dados para o Palaeolítico Superior final da Estremadura Portuguesa: resultados preliminares dos trabalhos arqueológicos de 1997-2003 na Lapa dos Coelhos (Casais Martanes, Torres Novas). Promontoria, 2,157-192.

ANTUNES M.T. 1989 - Castor fiber na gruta do Caldeirão. Existência, distribuição e extinção do castor em Portugal. Ciências da Terra, 10, 23-40.

BARISONE G., ARGENTI P. \& KOTSAKIS T., 2006 - PlioPleistocene Evolution of the Genus Castor (Rodentia, Mammalia) in Europe: C. Fiber Plicidens of Pietrafitta (Perugia, Central Italy). Geobios, 39, 757-770, doi: 10.1016/j.geobios.2005.10.004.

BEJENARU L., STANC S., POPOVICI M. \& BALASESCU A., 2013 - Beavers (Castor fiber) in the Past: Holocene Archaeological Evidence for Beavers in Romania. International Journal of
Osteoarchaeology, 25 (4), 375-391

BLASCO R., ROSELL J., SMITH K.T., MAUL L.C., SAÑUDO P., BARKAI R. \& GOPHER A., 2016 - Tortoises as a Dietary Supplement: A View from the Middle Pleistocene Site of Qesem Cave, Israel. Quaternary Science Reviews, 133, 165-182, doi: 10.1016/j.quascirev.2015.12.006.

CAMPBELL-PALMER R., GOW, D., NEEDHAM, R., JONES, S., ROSELL, F. 2012. Eurasian Beaver 56pp. Publisher: Pelagic Publishing, ISBN: 978-1784270346.

CONDE-VALVERDE M., QUAM R., MARTÍNEZ I., ARSUAGA J.-L., DAURA J., SANZ M. \& ZILHÃO J., 2018 - The bony labyrinth in the Aroeira 3 Middle Pleistocene cranium. Journal of Human Evolution, 124, 105-116.

CRUSAFONT PAIRÓ M., VILLALTA J.F. DE \& BATALLER J.R., 1948 - Los Castores Fósiles de España. Boletín del Instituto Geológico y Minero de España, 61, 321-349.

CUENCA-BESCÓS G., CANUDO J.I. \& LAPLANA C., 2001 - La séquence des rongeurs (Mammalia) des sites du Pléistocène Inférieur et Moyen d' Atapuerca (Burgos, Espagne). L'Anthropologie, 105, 115-130, doi : 10.1016/S0003-5521(01)80009-1.

CUENCA-BESCÓS G., LAPLANA C. \& CANUDO J.I. 1999 - Biochronological implications of the Arvicolidae (Rodentia, Mammalia) from the Lower Pleistocene Hominid-Bearing Level of Trinchera Dolina 6 (TD6, Atapuerca, Spain). Journal of Human Evolution, 37, 353-373, doi: 10.1006/jhev.1999.0306.

CUENCA-BESCÓS G., ROSELL ARDÉVOL J., MORCILLOAMO Á., GALINDO-PELLICENA M.Á., SANTOS E. \& MOYACOSTA R. 2017 - Beavers (Castoridae, Rodentia, Mammalia) from the Quaternary sites of the Sierra de Atapuerca, in Burgos, Spain. Ouaternary International, 433, 263-277.

DAURA J., SANZ M., ARSUAGA J.L., HOFFMANN D.L., QUAM R.M., ORTEGA M.C., SANTOS E., GÓMEZ S., RUBIO A. VILLAESCUSA L., SOUTO P., MAURICIO J., RODRIGUES F., FERREIRA A., GODINHO P., TRINKAUS E. \& ZILHÃO J., 2017 - New middle pleistocene hominin cranium from Gruta da Aroeira (Portugal). Proceedings of the National. Academy of Sciences, 114, 3397-3402.

DAURA J., SANZ M., DESCHAMPS M., MATIAS H., IGREJA M., VILLAESCUSA L., GÓMEZ S., RUBIO A., SOUTO $P$. RODRIGUES F. \& ZILHÃO J. 2018 - A 400,000-year-old Acheulean assemblage associated with the Aroeira-3 human cranium (Gruta da Aroeira, Almonda karst system, Portugal). Comptes Rendus Palevol, 17, 594-615.

DESCLAUX E., HANQUET C. \& EL GUENNOUNI K. 2011 - Origine(s) des accumulations de micromammifères dans quelques sites préhistoriques du Pléistocène moyen et supérieur d'Europe méridionale. In V. Laroulandie, J-B. Mallye \& C. Denys (éds.), Taphonomie des petits vertébrés : référentiels et transferts aux fossiles ; Actes de la Table Ronde du RTP Taphonomie, Talence 20-21 Octobre 2009. BAR International Series, 2269, 110-118.

DUCROZ J.-F., STUBBE M., SAVELJEV A.P., HEIDECKE D., SAMJAA R., ULEVIČIUS A., STUBBE A. \& DURKA W. 2005 - Genetic variation and population structure of the Eurasian Beaver Castor fiber in Eastern Europe and Asia. Journal of Mammalogy, 86, 1059-1067.

ERBAJEVA M. \& ALEXEEVA N., 2016 - Chapter 21, Late Cenozoic Mammal Faunas of the Baikalian Region Composition, Biochronology, Dispersal, and Correlation with Central Asia. In X. Wang, L.J. Flynn \& M. Fortelius (eds.), Fossil Mammals of Asia, Columbia University Press, 494-506.

FIORE I., GALA M. \& TAGLIACOZZO A., 2004 - Ecology and Subsistence Strategies in the Eastern Italian Alps during the Middle Palaeolithic. International Journal of Osteoarchaeology, 14, 273 286, doi: 10.1002/oa.761.

FOSTOWICZ-FRELIK L., 2008 - First record of Trogontherium cuvieri (Mammalia, Rodentia) from the middle Pleistocene of Poland and review of the species. Geodiversitas, 30, 765-778.

FREYE H.-A., 1978 - Castor Fiber Linnaeus, 1758 - Europäischer Biber. Handbuch der Säugetiere Europas, Band, 1, 184-200.

GARCÍA-ALIX A., MINWER-BARAKAT R., MARTÍN-SUÁREZ E. \& FREUDENTHAL M. 2007 - The southernmost record of fossil Castoridae (Mammalia, Rodentia) in Europe. Geodiversitas 29, 435-440.

HALLEY D.J., 2011 - Sourcing Eurasian beaver Castor fiber stock for reintroductions in Great Britain and Western Europe. Mammal Review, 41, 40-53.

HALLEY D.J. \& ROSELL F., 2002 - The beaver's reconquest of Eurasia: status, population development and management of a conservation success. Mammal Review, 32, 153-178.

HALLEY D.J. \& ROSELL F., 2003 - Population and distribution of European beavers (Castor fiber). Lutra, 46, 91-101.

HALLEY D.J., TEURLINGS I., WELSH H. \& TAYLOR C. 2013 - Distribution and patterns of spread of recolonising Eurasian beavers (Castor fiber Linnaeus 758) in fragmented habitat, Agdenes peninsula, Norway. Fauna Norvegica, 32, 1-12.

HUGUENEY M., 1999 - Family Castoridae. In G.E.Rössner \& 
K,Heissig (eds), The Miocene Land Mammals of Europe. Verlag Friedrich Pfeil, Munich, 281-300.

HUGUENEY M. 2004 - Les grands rongeurs du Pliocène supémrieur de Saint-Vallier (Drôme, France): Castoridae, Hystricidae (Mammalia, Rodentia). Geobios, 37, 126-132.

HUGUENEY M. \& ESCUILLIE F., 1996 - Fossil evidence for the origin of behavioral strategies in early Miocene Castoridae, and their role in the evolution of the family. Palaeobiology, 22, 507-513.

KORTH W., 2008 - Cranial Morphology, Systematics and Succession of Beavers from the Middle Miocene Valentine Formation of Nebraska, USA. Acta Palaeontologica Polonica, 53, 169-182, doi: 10.4202/app.2008.0201.

LEBRETON L., MOIGNE A.-M., FILOUX A. \& PERRENOUD C., 2017 - A specific small game exploitation for Lower Palaeolithic: The beaver (Castor fiber) exploitation at the Caune de l'Arago (Pyrénées-Orientales, France). Journal of Archaeological Science: Reports, 11, 53-58.

LIESAU VON LETTOW-VORBECK, C., 1998 - El Soto de Medinilla: Mammal faunas from the iberian Iron Age in the Duero valley (Valladolid, Spain). Archaeofauna, 7, 11-210.

LÓPEZ-GARCÍA J.M., BLAIN H.A., SANZ M., DAURA J., ZILHÃO, J. 2018 -Refining the environmental and climatic background of the Middle Pleistocene human cranium from Gruta da Aroeira (Torres Novas, Portugal). Quaternary Science Reviews, 200, 367-375.

MANNING A.D., COLES B.J., LUNN A.G., HALLEY D.J., ASHMOLE P. \& FALLON S.J., 2014 - New Evidence of Late Survival of Beaver in Britain. The Holocene, 24, 1849-1855, doi: 10.1177/0959683614551220.

MARKS A.E., BRUGAL J.-P., CHABAI V.P., MONIGAL K. GOLDBERG P., HOCKETT B., PEMAN E., ELORZA M., MALLOLL C. 2002a - Le gisement Pléistocène moyen de Galeria Pesada, (Estrémadure, Portugal) : premiers résultats. PALÉO. Revue d'archéologie préhistorique, 14, 77-100.

MARKS A.E., MONIGAL K., CHABAI V.P., BRUGAL J.-P., GOLDBERG P., HOCKETT B., PEMÁN E., ELORZA M. \& MALLOL C., 2002b - Excavations at the late Middle Pleistocene cave of Galeria Pesada, Portuguese Estremadura: 1997/1999. O Arqueólogo Português, 20, 7-38.

MEENTEMEYER R.K., VOGLER J.B., HILL C. \& BUTLER D.R., 1998 - The geomorphic influences of burrowing beavers on streambanks, Bolin Creek, North Carolina. Zeitschrift für Geomorphologie, 42, 453-468.

MÖRS T. \& STEFEN C., 2010 - The Castorid Steneofiber from NW Germany and Its Implications for the Taxonomy of Miocene Beavers. Acta Palaeontologica Polonica, 55, 189-198, doi: 10.4202/ app.2009.0013.

PERFECT C., GILVEAR D., LAW A. \& WILLBY N., 2015 - The Scottish Beaver Trial: Fluvial Geomorphology and River Habitat 2008-2013, Final Report. Scottish Natural Heritage, commissioned report no $683,33 \mathrm{p}$.

PÓVOAS L., ZILHAO J., CHALINE J. \& BRUNET-LECOMTE P., 1992 - La faune de rongeurs du Pleistocène Supérieur de la grotte de Caldeirao (Tomar, Portugal). Quaternaire, 3, 40-47, doi 10.3406/quate.1992.1971.

RENDU W., 2010 - Hunting Behavior and Neanderthal Adaptability in the Late Pleistocene Site of Pech-de-l'Azé I. Journal of Archaeological Science, 37 (8), 1798-1810, doi: 10.1016/j. jas.2010.01.037.

REPENNING C.A., 1968 - Mandibular Musculature and the Origin of the Subfamily Arvicolinae (Rodentia). Acta Zoologica Cracoviensia, 13, 29-72.

SALARI L., MASSETI M. \& SILVESTRI L., 2020 - Late Pleistocene and Holocene distribution history of the Eurasian beaver in Italy. Mammalia, 84, 259-277.

SANZ M., SALA N., DAURA J., PANTOJA-PÉREZ A., SANTOS E., ZILHÃO J., ARSUAGA J.L., 2018 - Taphonomic inferences about Middle Pleistocene hominins: The human cranium of Gruta da Aroeira (Portugal). American Journal of Physical Anthropoly, 167, 615-627.

SANZ M., DAURA J., CABANES D., ÉGÜEZ N., CARRANCHO Á., BADAL E., SOUTO P., RODRIGUES F. \& ZILHÃO J., 2020 - Early evidence of fire in south-western Europe: the Acheulean site of Gruta da Aroeira (Torres Novas, Portugal). Scientific Reports, 10, 12053.

SESÉ C. \& SOTO E., 1981 - Hallazgo de Castor Fiber L. En El Cuaternario de Asturias. Nuevos Datos Sobre La Distribución de La Especie En España. In Memoria del I Coloquio sobre Ecología y Biogeografia, Guadalajara, 1979, Sociedad Española de Ecología y Biogeografia, Excma. Diputación Provincial de Guadalajara, 244248.

SLIMAK L., LEWIS J.E., CRÉGUT-BONNOURE É., METZ L., OLLIVIER V., ANDRÉ P., CHRZAVZEZ J., GIRAUD Y., JEANNET M. \& MAGNIN F., 2010 - Le Grand Abri Aux Puces, a Mousterian Site from the Last Interglacial: palaeogeography, palaeoenvironment, and new excavation results. Journal of
Archaeological Science, 37 (11), 2747-2761.

STEFEN C. 2009 - Intraspecific variability of beaver teeth (Castoridae: Rodentia). Zoological Journal of the Linnean Society of London, 155, 926-936.

STINER M.C., MUNRO N.D., SUROVELL T.A., TCHERNOV E. \& BAR-YOSEF O., 1999 - Paleolithic Population Growth Pulses Evidenced by Small Animal Exploitation. Science, 283 (5399), 190194.

TRINKAUS E., MARKS A.E., BRUGAL J.-P., BAILEY S.E., JACK RINK W. \& RICHTER D., 2003 - Later Middle Pleistocene human remains from the Almonda Karstic System, Torres Novas, Portugal. Journal of Human Evolution, 45, 219-226.

TRINKAUS E., BAILEY S.E., DAVIS S.J.M. \& ZILHÃO J., 2011 - Magdalenian Human Remains from the Galeria da Cisterna (Almonda karstic system, Torres Novas, Portugal). O Arqueólogo Português, série 5, 1, 395-413.

VAN DE WEERD A/, 1976 - Rodent Faunas of the Mio-Pliocene Continental Sediments of TheTeruel-Alfambra Region, Spain. Utrecht Micropaleontological Bulletin, special publication 2, 218 p.

VILLAVERDE V. \& MARTÍ B., 1984 - Paleolitic i Epipaleolitic. Les Societats Caçadores de La Prehistoria Valenciana. Federico Domenech, Press, $133 \mathrm{p}$.

ZAVYALOV N.A., 2014 - Beavers (Castor fiber and Castor canadensis), the founders of habitats and phytophages. Biology Bulletin Reviews, 4, 157-180.

ZILHÃO J., 2009 - The Early Neolithic artifact assemblage from the Galeria da Cisterna (Almonda karstic system, Torres Novas, Portugal). In Collectif, De Méditerranée et d'ailleurs. Mélanges offerts à Jean Guilaine, Archives d'écologie préhistorique, Toulouse, 821-835.

ZILHÃO J., 2016 - Beaker people without beaker pots: the Chalcolithic funerary context from the Galeria da Cisterna (Almonda karst system, Torres Novas, Portugal). In Del neolític a l'edat del bronze en el Mediterrani occidental. Estudis en homenatge a Bernat Martí Oliver. Trabajos Varios. València, Servicio de Investigación Prehistórica, 119, 379-386.

ZILHÃO J., MAURÍCIO J. \& SOUTO P. 1991 - A Arqueologia da Gruta do Almonda. Resultados das escavações de 1988-89. In J.M. Arnaud (ed.), Actas das IV Jornadas Arqueológicas, investigação e defesa do património (Lisbo, 17, 18, 19 Maio 1990), Associação dos Arqueólogos Portugueses, 161-171.

ZILHÃO J., MAURÍCIO J. \& SOUTO P., 1993 - Jazidas arqueológicas do sistema cársico da nascente do Almonda. Nova Augusta, 7, 35-54.

ZILHÃO J., ANGELUCCI D.E., ARGANT J., BRUGAL J.-P., CARRIÓN J.S., CARVALHO R., FUENTES N. \& NABAIS M., 2010 - Humans and hyenas in the Middle Palaeolithic of Gruta da Oliveira (Almonda karstic system, Torres Novas, Portugal). In E. Baquedano \& J. Rosell (eds.), $1^{a}$ Reunion de Cientificos Sobre Cubiles de Hiena (y Otros Grandes Carnivoros) En Los Yacimientos Arqueologicos de La Peninsula Iberica. Zona Arqueologica, Museo Arqueologico Regional, Madrid, 13, 297-308

ZILHÃO J., ANGELUCCI D.E., ARAÚJO IGREJA M., ARNOLD L.J., BADAL E., CALLAPEZ P., CARDOSO J.L., D'ERRICO F., DAURA J., DEMURO M., DESCHAMPS M., DUPONT C., GABRIEL $S$, HOFFMANN D.L., LEGOINHA P., MATIAS H., MONGE SOARES A.M., NABAIS M., PORTELA P., QUEFFELEC A., RODRIGUES F. \& SOUTO P., 2020 - Last Interglacial Iberian Neandertals as Fisher-Hunter-Gatherers. Science, 367 (6485), eaaz7943, doi: 10.1126/science.aaz7943. 